\title{
The combined effects of feeding time and dietary fat levels on feed intake, growth and body composition in rainbow trout
}

\author{
Anne Gélineau ${ }^{\mathrm{a}, \mathrm{b}}$, Valérie Bolliet ${ }^{\mathrm{b}}$, Geneviève Corraze ${ }^{\mathrm{b}}$, Thierry Boujard ${ }^{\mathrm{b}, *}$ \\ a Aquitaine Aquaculture Sarl, 1, rue Marcel-David, 40004 Mont-de-Marsan, France \\ ${ }^{\mathrm{b}}$ INRA, Unité mixte Inra-Ifremer de Nutrition des Poissons, B.P. 3, 64310 Saint-Pée-sur-Nivelle, France
}

Received 20 March 2002; accepted 10 June 2002

\begin{abstract}
The combined effects of feeding time (morning and evening) and dietary fat concentration on feed intake, growth, body composition and lipid tissue distribution were examined in rainbow trout fed on demand. To that purpose, diets with low (LE, 6\% lipid) or high energy concentrations (HE, 24\% lipid) were used in four treatments that combined provision of the same (HE-HE or LE-LE) or different (HE-LE, LE-HE) diets at morning and evening meals. Digestible energy intakes of the LE-HE $\left(229 \mathrm{~kJ} \mathrm{~kg}^{-1} \mathrm{~d}^{-1}\right)$ and $\mathrm{HE}-\mathrm{HE}\left(269 \mathrm{~kJ} \mathrm{~kg} \mathrm{~d}^{-1}\right)$ groups were significantly different. There was no significant difference in the amount of energy intake between the two meals of the day in any of the treatments. The main effect of dietary treatment was on lipid intake; fish in the HE-HE, HE-LE and LE-HE treatments ingested approximately 3, 2.2 and 1.8 times more lipid than those on the LE-LE treatment. Growth, weight gain and protein gain were not affected by dietary treatment, but lipid gain reflected lipid intake; fish in the HE-HE, HE-LE and LE-HE treatments gained approximately 2.6, 2.1 and 1.7 more lipid than did fish on the LE-LE treatment. Body composition was significantly affected by dietary treatment; whole body lipid content reflected lipid gain, and visceral lipid concentration was affected in a similar way to whole-body lipid. On the other hand, muscle lipid concentrations were similar in fish submitted to the HE-LE, LE-HE, and LE-LE treatments $(<4 \%)$, and were lower than in fish on the HE-HE treatment (ca. 5.5\%). Consequently muscle lipid concentration was not directly related to lipid intake, because lipid intakes of fish on HE-LE and LE-HE treatments was higher than in those on the LE-LE treatment, while muscle lipid concentration was lower. Thus feeding fish with different diets in the morning and evening might have potential as a tool for manipulating lipid distributions and concentrations without major adverse effects on growth. (C) 2002 Ifremer/CNRS/Inra/IRD/Cemagref/Éditions scientifiques et médicales Elsevier SAS. All rights reserved.
\end{abstract}

\section{Résumé}

Effets combinés de l'heure d'alimentation et du taux de lipides alimentaires sur l'ingestion volontaire, la croissance et la composition corporelle chez la truite arc-en-ciel. Les effets combinés de l'heure d'alimentation et du taux de lipides alimentaires sur l'ingestion volontaire, la croissance, la composition corporelle et la distribution tissulaire des lipides ont été étudiés chez des truites arc-en-ciel nourries à la demande. Pour cela, des aliments dont l'apport en énergie était faible (LE, $6 \%$ lipides) ou élevé (HE, $24 \%$ lipides) ont été utilisés de façon à fournir soit le même aliment (traitements HE-HE ou LE-LE), soit un aliment différent (traitements HE-LE ou LE-HE) aux poissons durant les repas du matin et du soir. La quantité d'énergie digestible ingérée par les poissons, soumis aux traitements LE-HE $\left(229 \mathrm{~kJ} \mathrm{~kg}^{-1} \mathrm{j}^{-1}\right)$ et HE-HE $\left(269 \mathrm{~kJ} \mathrm{~kg}^{-1} \mathrm{j}^{-1}\right)$, était significativement différente. Il n'y avait, quels que soient les traitements, aucune différence significative de l'ingestion d'énergie digestible entre les deux repas de la journée. En fait, le principal effet du traitement sur l'ingestion concernait les lipides, et les poissons nourris, selon les protocoles HE-HE, HE-LE et LE-HE, ingéraient environ 3, 2,2 et 1,8 fois plus de lipides que ceux soumis au protocole LE-LE. La croissance, le gain de poids et le gain protéique n'étaient pas différents entre les traitements, mais le gain lipidique reflétait le taux d'ingestion de lipides, puisque les poissons soumis aux protocoles HE-HE, HE-LE et LE-HE ont eu un gain lipidique qui était environ 2,6, 2,1 et 1,7 fois plus important que ceux soumis au protocole LE-LE. La composition corporelle des poissons était significativement différente entre les traitements ; les taux de lipides corporels reflétant les gains lipidiques, et les taux de lipides péri-viscéraux étant affectés de la même façon que les lipides corporels totaux. Cependant, les concentrations lipidiques musculaires étaient similaires entre les poissons soumis aux protocoles HE-HE, LE-HE et LE-LE $(<4 \%)$ et significativement plus faibles

\footnotetext{
* Corresponding author.

E-mail address: boujard@st-pee.inra.fr (T. Boujard).
} 
que chez les poissons soumis au protocole HE-HE (5,5\%). Nous en concluons que le taux de lipides dans les muscles n'est pas directement corrélé au taux de lipides ingérés, car les poissons soumis aux traitements HE-LE et LE-HE ingéraient plus de lipides que ceux soumis au traitement LE-LE, et pourtant leur taux de lipides musculaires était plus faible. Il semble donc possible de manipuler la quantité et la répartition tissulaire des lipides de la truite arc-en-ciel d'élevage, en distribuant des aliments à teneur lipidique différente, le matin et le soir. (C) 2002 Ifremer/CNRS/Inra/IRD/Cemagref/Éditions scientifiques et médicales Elsevier SAS. Tous droits réservés.

Keywords: Feeding time; Lipid; Growth; Feed intake; Body composition; Oncorhynchus mykiss

\section{Introduction}

The feeding behaviour of fish has been much studied, and there are many indications that the time of feeding affects growth, feed efficiency and body composition (see review by Bolliet et al., 2001). It has been suggested that the optimal feeding time to promote growth might correspond to the natural daily peak of feeding activity of the species in question. For example, rainbow trout, Oncorhynchus mykiss, has a peak of feeding activity at dawn (Boujard and Leatherland, 1992a,b Sanchez-Vazquez and Tabata, 1998), and fish fed at dawn have higher weight gain than those fed at midnight (Boujard et al., 1995; Gélineau et al., 1996).

Daily changes in feeding activity may reflect adaptive responses to food availability and predators in the wild. There is also a considerable body of evidence that hormones or metabolites involved in feeding, growth and energy partitioning show significant daily fluctuations. This implies that fish are in different physiological states at different times of the day (see reviews by Boujard, 2001; Madrid et al., 2001), and as such, they respond differently to dietary treatments (rations or dietary compositions) depending on the time of feeding. This is exemplified by the study of Bolliet et al. (2000) on the combined effect of feeding time and dietary lipid levels on protein synthesis and retention. However, in that experiment, as with most studies concerned with the time of feeding, only one meal per day was provided. This is not usual practice in fish culture, so further studies are needed before the practical consequences of meal timing can be addressed.

The aim of the current study was to investigate the combined effects of feeding time and dietary fat levels on feed intake and growth characteristics of rainbow trout fed twice daily. Fish were fed low (LE, 6\% lipid) or a high (HE, $24 \%$ lipid) energy diets in combinations that gave distributions of the same or different diets in the two meals.

\section{Materials and methods}

\subsection{Experimental conditions}

The experiment was conducted at Inra, Saint-Pée-surNivelle (Pyrénées-Atlantiques, France) over a period of 7 weeks. The photoperiod was $13.5 \mathrm{~h}$ light/10.5 h dark (lights on at 05:00 hours) with dawn and dusk periods of $30 \mathrm{~min}$ each. Tanks (100 1) were supplied with re-circulated water at a flow rate of $21 \mathrm{~min}^{-1}$ and temperature maintained at $16.0 \pm 0.2{ }^{\circ} \mathrm{C}$. Each tank was equipped with a demandfeeder system (Imetronic Sarl, France), comprising a trigger placed $5 \mathrm{~mm}$ above the water surface, a food hopper, an interface and control software that recorded trigger signals and controlled the feeder (Boujard et al., 1992). Access to food was for two periods of $2.5 \mathrm{~h}$ each per day, between 05:00 and 07:30 hours (morning meal) and between 17:00 and 19:30 hours (evening meal). During these two periods trigger actuations were rewarded by provision of food (ca. $0.5 \mathrm{~g}$ ). Each tank was equipped with a sediment trap for collection of any waste feed.

Rainbow trout of initial body weight of approximately $30 \mathrm{~g}$ were divided into groups of 30 fish each and distributed among the 12 tanks. They were fed iso-nitrogenous $3 \mathrm{~mm}$ dry pellets formulated to contain approximately 240 or $60 \mathrm{~g}$ lipid $\mathrm{kg}^{-1}$ dry matter (HE and LE; Table 1). Four dietary treatments were established, each being applied to three groups of fish: HE diet at both meals (HE-HE treatment), LE diet at both meals (LE-LE treatment), HE diet in the morning and LE diet in the evening (HE-LE treatment), LE diet in the morning and HE diet in the evening (LE-HE treatment).

\subsection{Sample collection and analytical methods}

At the start of the trial, 10 fish were sampled for proximate analysis of the whole body, and at the end of the trial, four fish per tank were sampled for composition analysis. Liver, viscera and muscle were sampled from an additional three fish per tank. The samples were frozen in liquid nitrogen and stored at $-80{ }^{\circ} \mathrm{C}$ until analysed for lipid content.

Whole fish were homogenised and freeze-dried prior to analysis. Chemical compositions of diets and whole fish were analysed as follows: dry matter after drying at $105{ }^{\circ} \mathrm{C}$ for $24 \mathrm{~h}$, fat after extraction with petroleum ether by the Soxhlet method, starch by the glucose-amylase-glucoseoxidase method (Thivend et al., 1972), protein $(\mathrm{N} \times 6.25)$ by the Kjeldahl method after acid digestion. Gross energy was determined using a adiabatic bomb calorimeter. Due to small sample sizes the liver, viscera and muscle samples were homogenised and total lipids were determined using a modification of the method of Folch et al. (1957); chloroform being replaced by dichloromethane. 
Table 1

Ingredients, proximate composition and digestible content of the experimental diets HE and LE

\begin{tabular}{|c|c|c|}
\hline Diets & $\mathrm{HE}$ & $\mathrm{LE}$ \\
\hline \multicolumn{3}{|l|}{ Ingredients $\left(\mathrm{g} \mathrm{kg}^{-1}\right)$} \\
\hline Fish meal a & 572 & 572 \\
\hline Fish oil & 186 & 15 \\
\hline Crude starch & 0 & 247 \\
\hline Gelatinised starch & 212 & 136 \\
\hline Vitamin mixture $^{b}$ & 10 & 10 \\
\hline Mineral mixture $^{\mathrm{c}}$ & 10 & 10 \\
\hline Binder (sodium alginate) & 10 & 10 \\
\hline \multicolumn{3}{|l|}{ Proximate composition } \\
\hline Dry matter $(\mathrm{DM})\left(\mathrm{g} \mathrm{kg}^{-1}\right)$ & 932 & 913 \\
\hline Crude protein $(\mathrm{N} \times 6.25)\left(\mathrm{g} \mathrm{kg}^{-1} \mathrm{DM}\right)$ & 404 & 411 \\
\hline Crude fat $\left(\mathrm{g} \mathrm{kg}^{-1} \mathrm{DM}\right)$ & 246 & 64 \\
\hline Starch $\left(\mathrm{g} \mathrm{kg}^{-1} \mathrm{DM}\right)$ & 184 & 370 \\
\hline Gross energy ( $\left.\mathrm{kJ} \mathrm{g}^{-1} \mathrm{DM}\right)$ & 23.5 & 19.5 \\
\hline \multicolumn{3}{|l|}{ Digestible content } \\
\hline Digestible protein (DP) $\left(\mathrm{g} \mathrm{kg}^{-1}\right.$ of DM) ${ }^{\mathrm{d}}$ & 369 & 372 \\
\hline Digestible energy (DE) $\left(\mathrm{kJ} \mathrm{g}^{-1} \mathrm{DM}\right)^{\mathrm{e}}$ & 21.2 & 16.6 \\
\hline $\mathrm{DP} / \mathrm{DE}\left(\mathrm{mg} \mathrm{kJ}^{-1}\right)$ & 17.4 & 22.4 \\
\hline
\end{tabular}

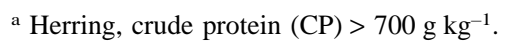

b As per NRC (1993).

${ }^{\mathrm{c}}$ Per kg diet: $1.12 \mathrm{~g} \mathrm{CaCO}_{3}(40 \% \mathrm{Ca}) ; 0.62 \mathrm{~g} \mathrm{MgO}(60 \% \mathrm{Mg}) ; 0.1 \mathrm{~g}$ ferric citrate; $0.2 \mathrm{mg} \mathrm{KI}(75 \% \mathrm{I}) ; 0.2 \mathrm{~g} \mathrm{ZnSO}$ ( $\left.36 \% \mathrm{Zn}\right) ; 0.15 \mathrm{~g} \mathrm{CuSO} 4(25 \% \mathrm{Cu})$; $0.15 \mathrm{~g} \mathrm{MnSO}_{4}(33 \% \mathrm{Mn}) ; 2.5 \mathrm{~g} \mathrm{Ca}_{3}\left(\mathrm{PO}_{4}\right)_{2}(20 \% \mathrm{Ca}, 18 \% \mathrm{P}) ; 1 \mathrm{mg} \mathrm{CoSO} ; 1.5 \mathrm{mg}$ sodium selenite $(30 \% \mathrm{Se}) ; 0.45 \mathrm{~g} \mathrm{KCl} ; 0.2 \mathrm{~g} \mathrm{NaCl}$.

${ }^{\mathrm{d}}$ DP was calculated assuming a digestibility coefficient value of 91.3\% for HE diet and 90.5\% for LE diet (Boujard and Médale, 1994).

e DE was calculated assuming digestibility coefficient values of 90.3\% for HE diet and 85.3\% for LE diet (Boujard and Médale, 1994).

\subsection{Analysis of data}

Feed intake, growth and feed utilisation were described according to the following:

- FI, average relative daily feed intake: total feed ingested/ABW/days;

- \%FI during morning meal: $100 \times$ FI morning/(FI morning + FI evening);

- LI or PI, lipid or protein intake: total lipid or protein ingested/ABW/days;

- DEI, average relative daily digestible energy intake $\left(\mathrm{kJ} \mathrm{kg}^{-1}\right): 1000 \times(($ total HE diet ingested $\times \mathrm{DE}$ of diet $\mathrm{HE})+($ total LE diet ingested $\times \mathrm{DE}$ of diet $\mathrm{LE}) / \mathrm{ABW} /$ days $\%$;

- DEI during morning meal: $100 \times$ DEI morning/(DEI morning + DEI evening);

- SGR, Specific growth rate: $100 \times(\ln (\mathrm{FBW})-$ $\ln (\mathrm{IBW})) /$ days;

- Gain: FBW - IBW;

- Protein or lipid gain: (final protein or lipid concentration $\times$ FBW $)-($ initial protein or lipid concentration $\times$ IBW);

- Protein or energy retention efficiencies: $100 \times(($ final protein or energy concentration $\times \mathrm{FBW}$ ) - (initial protein or energy concentration $\times$ IBW $)$ )/(Total dry feed ingested $\times$ protein or energy concentration in the diet), where IBW is the initial mean body weight; FBW, the final mean body weight; ABW, the average body weight: $(\mathrm{IBW}+\mathrm{FBW}) / 2$; total feed ingested, the feed distributed feed wasted; DE of diets HE or LE, the digestible energy content of diets HE or LE $\left(\mathrm{kJ} \mathrm{g}^{-1}\right)$.
All statistical analyses were performed using GraphPad Prism $^{\mathrm{TM}}$ version 3.02 for Windows (GraphPad Software, San Diego California USA). Percentage data were Arcsin $\sqrt{(x)}$ transformed prior to analysis. The influence of dietary treatment was tested by one-way Anova for each variable and Tukey's multiple comparison test was performed when $F$ values indicated significance $(p<0.05)$. A one-sample $t$-test of comparison with a hypothetical value of $50 \%$ was used to evaluate the effect of dietary treatment on the share of intake between the two meals.

\section{Results}

\subsection{Intake and growth regulation}

No mortality was observed during the trial. The amount of feed waste was always $<2 \%$ of the total distributed. Feed intake was significantly higher in fish on the LE-LE treatment than in the other groups, but protein intake did not differ among treatments. Lipid intake was different across all treatments, and digestible energy intake was significantly lower in the fish on the LE-HE treatment than in those on the HE-HE treatment (Table 2). Fish fed the same diet in the two meals (HE-HE and LE-LE) ate almost the same amount in both meals of the day, whereas fish in the other groups (HE-LE and LE-HE) tended to eat more during the morning meal than during the evening meal (Fig. 1), but this was significant only for fish on the LE-HE treatment $(t=4.469 ; \mathrm{df}=2 ; p<0.05)$. However, for fish on this 
Table 2

Effect of dietary treatment (HE-HE, HE-LE, LE-HE or LE-LE) on intake (feed intake, protein intake, lipid intake, digestible energy) and growth (specific growth rate, weight gain, protein and lipid gain) parameters. See main text for designations of dietary treatments. Data are given as means \pm S.D., $n=3$. The $F$ value and the $p$ levels of the Anova are indicated, and values within the same row with different letters are significantly different $(p<0.05)$. Initial numbers of fish and initial fish weights were 30 and $27.3 \pm 0.4$, respectively

\begin{tabular}{|c|c|c|c|c|c|c|}
\hline & $\mathrm{HE}-\mathrm{HE}$ & HE-LE & LE-HE & LE-LE & $F$ & $p$ \\
\hline \multicolumn{7}{|l|}{ Intake } \\
\hline FI $\left(\% B W d^{-1}\right)$ & $1.3 \pm 0.1 \mathrm{a}$ & $1.3 \pm 0.1 \mathrm{ab}$ & $1.2 \pm 0.1 \mathrm{a}$ & $1.5 \pm 0.1 \mathrm{~b}$ & 7.94 & $<0.01$ \\
\hline PI $\left(\mathrm{g} \mathrm{kg}^{-1} \mathrm{~d}^{-1}\right)$ & $5.1 \pm 0.3$ & $5.4 \pm 0.5$ & $5.4 \pm 0.8$ & $6.1 \pm 0.2$ & 3.13 & 0.087 \\
\hline LI $\left(\mathrm{g} \mathrm{kg}^{-1} \mathrm{~d}^{-1}\right)$ & $3.1 \pm 0.2 \mathrm{a}$ & $2.2 \pm 0.1 \mathrm{~b}$ & $1.8 \pm 0.3 \mathrm{c}$ & $1.0 \pm 0.1 \mathrm{~d}$ & 105.2 & $<0.001$ \\
\hline DEI $\left(\mathrm{kJ} \mathrm{kg}^{-1} \mathrm{~d}^{-1}\right)$ & $269 \pm 14 a$ & $254 \pm 19 a b$ & $229 \pm 10 b$ & $247 \pm 7 \quad a b$ & 6.47 & $<0.05$ \\
\hline \multicolumn{7}{|l|}{ Growth } \\
\hline $\operatorname{SGR}\left(\% \mathrm{BW} \mathrm{d}^{-1}\right)$ & $1.7 \pm 0.1$ & $1.7 \pm 0.3$ & $1.6 \pm 0.1$ & $1.6 \pm 0.1$ & 0.87 & 0.494 \\
\hline Gain $(g)$ & $31.4 \pm 0.7$ & $31.9 \pm 6.9$ & $27.6 \pm 1.0$ & $28.3 \pm 1.5$ & 1.09 & 0.409 \\
\hline Protein gain $(\mathrm{g})$ & $4.5 \pm 0.1$ & $4.7 \pm 0.9$ & $4.1 \pm 0.2$ & $4.5 \pm 0.2$ & 0.79 & 0.534 \\
\hline Lipid gain (g) & $4.4 \pm 0.5 \mathrm{a}$ & $3.6 \pm 1.3 \mathrm{~b}$ & $2.8 \pm 0.2 b$ & $1.7 \pm 0.4 \mathrm{c}$ & 21.76 & $<0.001$ \\
\hline
\end{tabular}
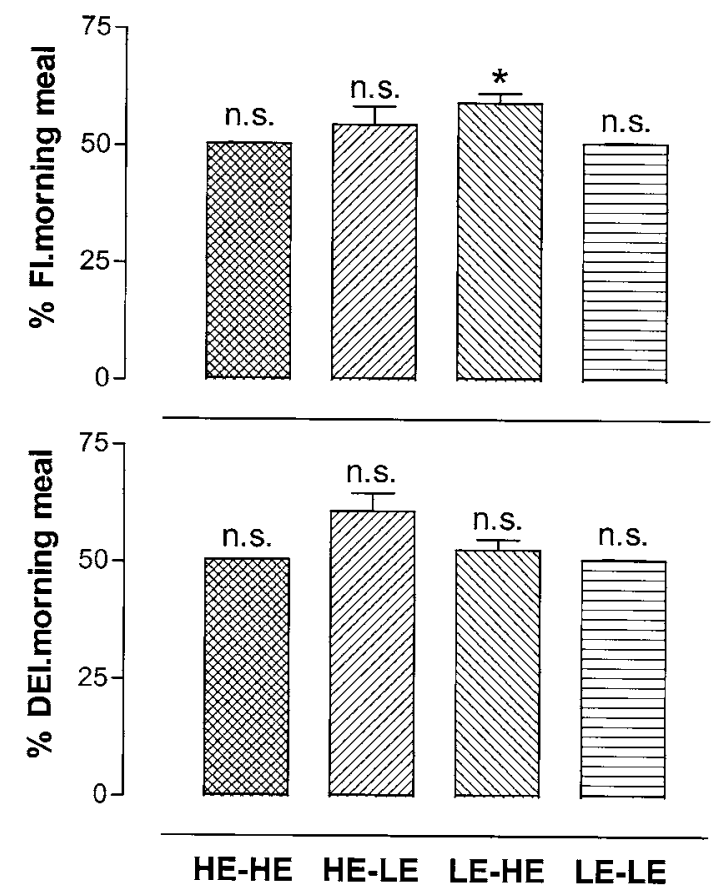

Fig. 1. Effect of dietary treatment (HE-HE, HE-LE, LE-HE or LE-LE) on the proportion of feed intake $(\% \mathrm{FI})$ and digestible energy intake (\%DEI) observed during the morning meal. See main text for designations of dietary treatments. $*$ Significantly different from $50 \%(p<0.05)$; n.s. not significantly different from $50 \%$. Whiskers indicate S.D. treatment energy intake (DEI) was not significantly different between meals $(t=1.254 ; \mathrm{df}=2 ; p=0.3365)$. The groups of fish submitted to the HE-LE treatment tended to ingest more energy during the morning meal than during the evening meal, but this was not significant from a 50:50 distribution $(t=2.838 ; \mathrm{df}=2 ; p=0.1050)$ (Fig. 1).

The different treatments did not result in any significant differences in terms of weight gain, protein gain or SGR, although there was a trend for better growth in groups fed the HE diet in the morning (Table 2). Both lipid intake and lipid gain were markedly affected by dietary treatment, both being highest for fish on the HE-HE treatment and lowest for LE-LE fish (Table 2).

\subsection{Body composition and nutrient retention}

Dietary treatment significantly affected the proximate composition of the fish (Table 3). Fish submitted to the HE-HE treatment were the fattest, had the highest energy content, and the lowest protein concentration, while those submitted to the LE-LE treatment were the leanest, with the lowest energy content and the highest protein concentration. Protein and energy retention efficiencies were not significantly affected by dietary treatment, but tended to be lowest in the fish on the LE-LE treatment.

There was no significant effect of dietary treatment on the liver lipid concentration (Fig. 2), but both the visceral and

Table 3

Effect of dietary treatment (HE-HE, HE-LE, LE-HE or LE-LE) on final proximate composition of the fish (dry matter, total protein (N $\times 6.25)$, total lipid and energy gain, and protein and energy retention efficiencies. See main text for designations of dietary treatments. Initial proximate composition was dry matter $=25.4 \%$ body weight, protein $=15.9 \%$, lipid $=5.7 \%$, energy $=6.1 \mathrm{~kJ} \mathrm{~g}^{-1}$ body weight. Data are given as means \pm S.D., $n=3$. For each variable, the $F$ value and the $P$ levels of the Anova are indicated. Values within the same row with different letters are significantly different $(p<0.05)$

\begin{tabular}{|c|c|c|c|c|c|c|}
\hline & HE-HE & HE-LE & LE-HE & LE-LE & $F$ & $p$ \\
\hline \multicolumn{7}{|c|}{ Proximate composition ( $\%$ or $\mathrm{kJ} \mathrm{g}^{-1}$ body weight) } \\
\hline Dry matter & $28.7 \pm 1.4$ & $27.9 \pm 0.9$ & $27.6 \pm 0.9$ & $25.9 \pm 0.6$ & 3.98 & 0.052 \\
\hline Protein & $15.0 \pm 0.2 b$ & $15.2 \pm 0.3 \mathrm{ab}$ & $15.4 \pm 0.3 \mathrm{ab}$ & $15.9 \pm 0.1 \mathrm{a}$ & 6.09 & $<0.05$ \\
\hline Lipid & $10.1 \pm 0.9 \mathrm{a}$ & $8.7 \pm 1.2 \mathrm{ab}$ & $8.0 \pm 0.5 b c$ & $5.9 \pm 0.6 c$ & 13.35 & $<0.01$ \\
\hline Energy & $7.4 \pm 0.5 \mathrm{a}$ & $7.1 \pm 0.4 \mathrm{ab}$ & $6.9 \pm 0.3 \mathrm{ab}$ & $6.2 \pm 0.2 b$ & 5.91 & $<0.05$ \\
\hline \multicolumn{7}{|c|}{ Retention efficiencies (\%) } \\
\hline Protein $(\%)$ & $45.4 \pm 2.7$ & $43.8 \pm 0.8$ & $46.3 \pm 4.2$ & $39.6 \pm 2.2$ & 3.45 & 0.072 \\
\hline Energy (\%) & $51.7 \pm 8.2$ & $50.3 \pm 6.1$ & $51.3 \pm 1.8$ & $39.0 \pm 4.1$ & 3.50 & 0.070 \\
\hline
\end{tabular}



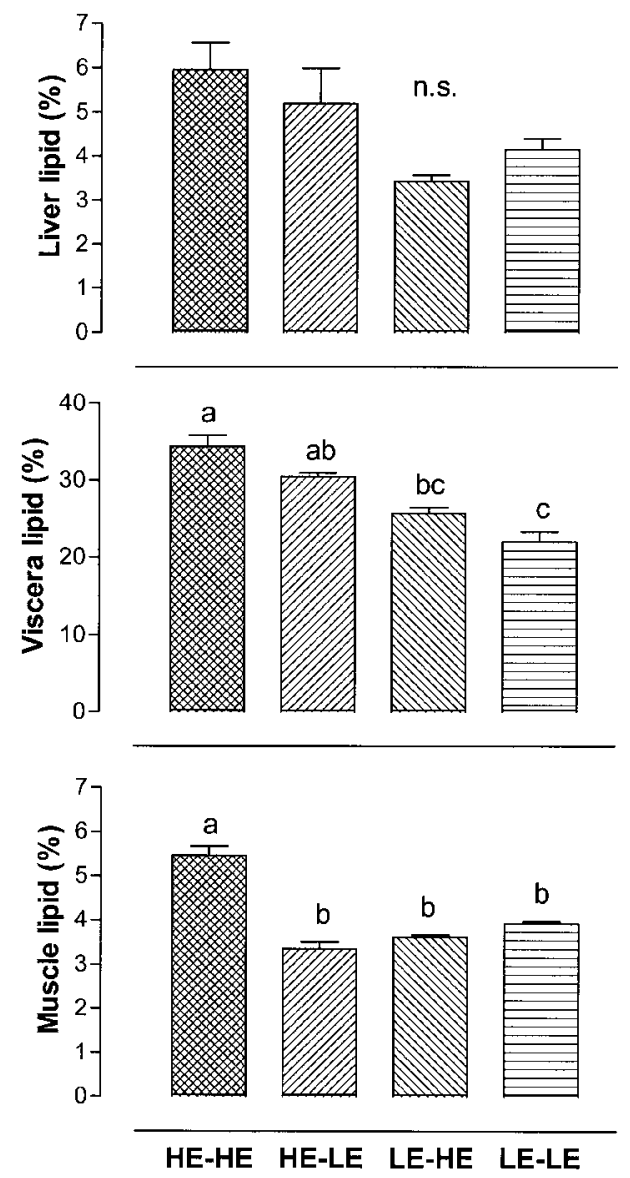

Fig. 2. Effect of dietary treatment (HE-HE, HE-LE, LE-HE or LE-LE) on liver, viscera and muscle lipid concentration. Bars with different letters are significantly different $(p<0.05)$; n.s. not significant. Whiskers indicate S.D.

muscle lipid concentrations were affected by dietary treatment. In the case of the viscera, lipid concentrations varied a similar way to whole-body lipid concentrations (cf. Table 2 and Fig. 2), but this was not the case for muscle lipid concentrations. Muscle lipid concentrations were low in fish submitted to the HE-LE, LE-HE and LE-LE treatments, in comparison to the fish fed the HE diet only, and muscle lipid concentration was not directly related to lipid intake (Fig. 3). Lipid intake of fish on the HE-LE and LE-HE was higher than that of fish fed the LE diet only, but their muscle lipid concentrations were significantly lower $(F=64.9$; $p<0.0001$; one-way ANOVA and Tukey's post-hoc test).

\section{Discussion}

\subsection{Intake and growth regulation}

Growth was similar to that observed previously in fish held under similar feeding conditions (on demand with time-restricted access to food; Gélineau et al., 1998, 2001). However, hand-feeding of rainbow trout tends to promote better growth, implying that self-fed trout with time-

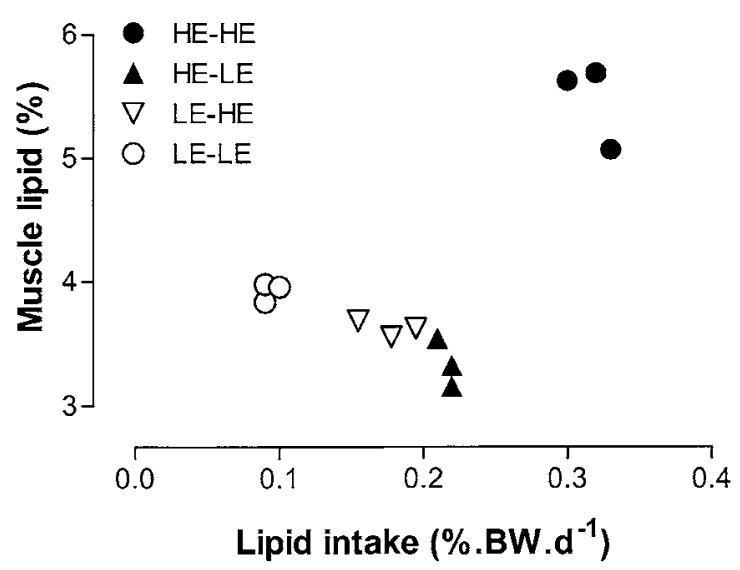

Fig. 3. Scatter plot showing relationship between lipid intake $\left(\% \mathrm{BW} \mathrm{d} \mathrm{d}^{-1}\right)$ and final muscle lipid concentration for fish submitted to the different dietary treatment (HE-HE, HE-LE, LE-HE or LE-LE).

restricted access to food do not achieve maximal growth (Gélineau et al., 1998, 2001). When fish are fed by means of self-feeders, they must actively seek food and feed delivery stops when the fish that operate the feeding system cease activating the trigger. In groups of fish that are hand-fed to satiation, food is provided as long as the fish display a feeding response. This suggests that rainbow trout fed on demand do not ingest as much food as they are able, but feed in relation to the effort required to obtain food.

With the exception of the groups submitted to the LE-HE treatment, there appeared to be regulation of daily feed intake based on dietary digestible energy content (DEI not significantly different between HE-HE, HE-LE and LE-LE treated groups). This is in accordance with previous studies with rainbow trout fed either on demand (Boujard and Médale, 1994; Gélineau et al., 2001) or by hand (Lee and Putnam, 1973; Kaushik and Oliva-Teles, 1985; Beamish and Medland, 1986). However, there was a trend for higher energy intake (and growth) in fish fed the high energy diet in the morning; this may indicate that fish experience some difficulty in regulating their energy intake when the diets delivered in the morning and evening differ. Bolliet et al. (2000) suggested that time of feeding and dietary fat interact to affect growth, but they presented food only once per day. In the present study there were no significant differences between the groups of fish submitted to the dissociated dietary treatments (HE-LE or LE-HE), so it appears that overall feed intake and feed efficiency were primarily influenced by total energy intake, and only marginally by the time of access to the two diets (LE and HE).

\subsection{Body composition and nutrient retention}

The effects of dietary treatment on proximate body composition were in line with results of previous studies (Takeuchi et al., 1978; Kaushik and Oliva-Teles, 1985; Jobling et al., 1998; Gélineau et al., 2001), and the differences in lipid deposition observed among fish submitted to 
the different dietary treatments could be linked to the composition of the diets. Fish submitted to the HE-HE, $\mathrm{HE}-\mathrm{LE}$ and LE-HE treatments ingested approximately 3, 2.2 and 1.8 times more lipid than those on the LE-LE treatment, and this was reflected in fat deposition and body composition.

Boccignone et al. (1993) reported a significant increase in muscle lipid concentration in rainbow trout fed during late afternoon in comparison with those fed in the morning, whereas Bellardi et al. (1995) reported that perivisceral fat was higher in fish fed in the morning than in fish fed during late afternoon. In the present study the lowest muscle lipid concentrations were observed in the fish submitted to the dissociated (HE-LE and LE-HE) dietary treatments. However, in the absence of data from a treatment using a diet with intermediary fat levels distributed at both meals, it cannot be determined if this was the effect of the dynamics of lipid intake and distribution, or the effect of the dietary treatment per se. If our observation is one reflecting dietary treatment, it implies that ingestion of a large amount of lipid in one of two meals per day (HE distributed in the morning or in the evening and LE given at the other meal) does not induce any greater fat deposition in the muscle of small rainbow trout than does the provision of a low fat diet (LE) in both meals.

This result indicate that feeding fish with diets that differ in composition in the morning and evening meal may have potential as a tool for manipulating body, and particularly muscle, composition.

\section{Acknowledgements}

We thank M. Jobling for advice and helpful comments on the manuscript. The first author benefited from a CIFRE scholarship partly funded by the French Ministry of Research and Higher Education. This study was financially supported by the Conseil Régional d'Aquitaine.

\section{References}

Beamish, F.W.H., Medland, T.E., 1986. Protein sparing effects in large rainbow trout, Salmo gairdneri. Aquaculture 55, 35-42.

Bellardi, S., Bianchini, M.L., Domenis, L., Palmegiano, G.B., 1995. Effect of feeding schedule and feeding rate on size and number of adipocytes in rainbow trout, Oncorhynchus mykiss. J. World Aquac. Soc. 26, 80-83.

Boccignone, M., Forneris, G., Salvo, F., Ziino, M., Leuzzi, U., 1993. Size and meal timing: effect on body composition in rainbow trout. In: Kaushik, S.J., Luquet, P. (Eds.), Fish Nutrition in Practice. Les Colloques INRA, n 61, Paris, France, pp. 293-296.
Bolliet, V., Azzaydi, M., Boujard, T., 2001. Effects of feeding time on feed intake and growth. In: Boujard, T., Jobling, M., Houlihan, D. (Eds.), Food intake in fish. Blackwell Science, Oxford, UK, pp. 233-249.

Bolliet, V., Cheewasedtham, C., Houlihan, D., Gélineau, A., Boujard, T., 2000. Effect of feeding time on digestibility, growth performance and protein metabolism in the rainbow trout Oncorhynchus mykiss: interactions with dietary fat levels. Aquat. Living Resour. 13, 107-113.

Boujard, T., 2001. Daily feeding rhythms and fish physiology. Vie Milieu 51, 237-245.

Boujard, T., Leatherland, J.F., 1992. a. Demand-feeding behaviour and diet pattern of feeding activity in Oncorhynchus mykiss held under different photoperiod regimes. J. Fish Biol. 40, 535-544.

Boujard, T., Leatherland, J.F., 1992b. Circadian rhythms and feeding time in fishes. Environ. Biol. Fish 35, 109-131.

Boujard, T., Médale, F., 1994. Regulation of voluntary feed intake in juvenile rainbow trout fed by hand or by self-feeders with diets containing two different protein/energy ratios. Aquat. Living Resour. 7, 211-215.

Boujard, T., Dugy, X., Genner, D., Gosset, C., Grig, G., 1992. Description of a modular, low cost, eater meter for the study of feeding behavior and food-preferences in fish. Physiol. Behav. 52, 1101-1106.

Boujard, T., Gelineau, A., Corraze, G., 1995. Time of a single daily meal influences growth performance in rainbow trout. Aquac. Res. 26, 341-349.

Folch, J., Lees, M., Sloane-Stanley, G.H.S., 1957. A simple method for the isolation and purification of total lipids from animal tissues. J. Biol. Chem. 226, 497-509.

Gélineau, A., Corraze, G., Boujard, T., 1998. Effects of restricted ration, time restricted access and reward level on voluntary food intake, growth and growth heterogeneity of rainbow trout fed on demand with self-feeders. Aquaculture 167, 247-258.

Gélineau, A., Corraze, G., Boujard, T., Larroquet, L., Kaushik, S., 2001. Relation between dietary lipid level and voluntary feed intake, growth, nutrient gain and hepatic lipogenesis in rainbow trout. Reprod. Nutr. Dev. 41, 487-503.

Gélineau, A., Mambrini, M., Leatherland, J.F., Boujard, T., 1996. Effect of feeding time on hepatic nucleic acid, plasma $\mathrm{T}_{3}, \mathrm{~T}_{4}$, and GH concentrations in rainbow trout. Physiol. Behav. 59, 1061-1067.

Jobling, M., Koskela, J., Savolainen, R., 1998. Influence of dietary fat level and increased adiposity on growth and fat deposition in rainbow trout Oncorhynchus mykiss (Walbaum). Aquac. Res. 29, 601-607.

Kaushik, S.J., Oliva-Teles, A., 1985. Effect of digestible energy on nitrogen and energy balance in rainbow trout. Aquaculture 50, 89-101.

Lee, D.J., Putnam, G.B., 1973. The response of rainbow trout to varying protein/energy ratios in a test diet. J. Nutr. 103, 916-922.

Madrid, J.A., Boujard, T., Sánchez-Vázquez, F.J., 2001. Feeding rhythms. In: Houlihan, D., Boujard, T., Jobling, M. (Eds.), Food intake in fish. Blackwell Science, Oxford, pp. 189-215.

(NRC) National Research Council, 1993. Nutrient requirements of fish. National Academy of Sciences, Washington DC, pp. 102.

Sanchez-Vazquez, F.J., Tabata, M., 1998. Circadian rhythms of demandfeeding and locomotor activity in rainbow trout. J. Fish Biol. 52, 255-267.

Takeuchi, T., Watanabe, T., Ogino, C., 1978. Supplementary effect of lipids in a high protein diet for rainbow trout. Bull. Jpn. Soc. Sci. Fish 44, 677-681.

Thivend, P., Mercier, C., Guilbot, A., 1972. Determination of starch with glucoamylase. In: Whistler, R.L., Bemiller, J.N. (Eds.), Methods in Carbohydrate Chemistry, vol. VI. Academic Press, New York, pp. 100-105. 